\title{
MODELLING OF THE SYSTEM OF THE DEVELOPMENT OF FUNCTIONAL MATHEMATICAL LITERACY IN STUDENTS HAVING MODERATE SPECIAL EDUCATIONAL NEEDS IN PRACTICE: PEDAGOGUES' APPROACH
}

\section{Ingrida Baranauskienè}

Laima Tomènienè

Šiauliai University, Lithuania

\begin{abstract}
The article deals with the strategies used in of mathematical education, while creating the methodology of the development of mathematical literacy in senior class students of mainstream schools having moderate special educational needs oriented towards the development of functional students' abilities in practice. 20 pedagogues (teachers of mathematics and special pedagogues) developing mathematical abilities of 30 students having moderate special educational needs in the $8^{\text {th }}$ forms of mainstream schools participated in the action research. As it is shown in the scientific literature, the performed action research has been analyzed: its peculiarities and strategies of application in creating the methodology of the development of functional mathematical literacy in students with moderate special educational needs in the $8^{\text {th }}$ form of mainstream school have been revealed.
\end{abstract}

Key words: action research, functional development of students' abilities, mathematical literacy, students having moderate special educational needs.

\section{Introduction}

Problems and relevance of the research. Modern directions of education are oriented towards a new concept of pragmatism education that accentuates student's activeness, ability to solve real life problems (practical, personal, social); brings education closer to students' actual social environment; the attitude that students trying to find the solutions of the problems start to better understand and control their life is followed; the role of educators in helping a person is accentuated; the variety of the forms of education, active teaching methods are important (Dewey, 2000; Ozmon, Craver, 1996; Bitinas, 2000). Referring to a new attitude towards the process of education, study subjects in educating students with SEN should be related to real life situations and their solution. According to the representatives of pragmatism, education should be considered not as getting ready for life but as life itself, action, process (Dewey, 2000; Ozmon, Craver, 1996). The precondition has been made that in the structure of education of students with special educational needs not knowledge itself or social ideas should be important but individual ability to use societal experience in solving personally relevant problems. Education should be oriented towards action so that students get acquainted with interrelations between various kinds of knowing and learn to apply them in solving real life problems, which is especially relevant for students with moderate and severe special educational needs, who from 1 September 2012 according to new 
documents regulating special education in Lithuania after the graduation from basic education individualizing or adapting General Programmes of Subjects are offered to continue education according to the programme of vocational education

In scientific literature it is indicated that a teacher under new conditions of learning paradigm should be a practitioner, organizer of students' work, counsellor. It also conditions new importance and new requirements for the organization of the process of education for students with more severe special educational needs, for teaching and learning subjects in mainstream school. Applied methods, educational environments should help students to relate gained knowledge to practical activity, to real life, to teach how to solve problems posed by real life surroundings and real life situations. It increases learning motivation of students with special educational needs, their interest in learning process; helps to get ready for independent life, choosing a profession and teaching (learning).

In the contemporary world full of numbers, quantitative expression, constant perfection of technologies and change of information, pedagogues face many problematic questions how to organize the system of mathematical education for senior class students of mainstream schools having moderate special educational needs that optimizes the development of functional mathematical literacy; how to teach students having moderate special educational needs so that their practical mathematical and general abilities necessary for successful socialization in contemporary society are developed; how to organize work in classroom when students' needs are very different.

Aim of the research - to reveal the changes of pedagogues' approach to the strategies of modelling the system of mathematical education, while creating the methodology of the development of mathematical literacy in senior class students of mainstream schools having moderate special educational needs oriented towards the development of functional students' abilities in practice.

Object of the research - the pedagogues' approach to modelling of the system of the development of functional mathematical literacy in students having moderate special educational needs in practice.

Sample of the research - 20 pedagogues (teachers of mathematics and special pedagogues) developing mathematical abilities in students with moderate special educational needs in $8^{\text {th }}$ forms of mainstream schools.

Methods of the research - analysis of scientific literature; action research using the method of focus group.

\section{Methodology, organization and results of the research}

During the recent decade in Lithuania new education documents have been prepared, where new aims of education were formulated and the directions of 
further change in education that became the basis in updating General Programmes of primary and basic education (2008) have been drawn, - bigger orientation towards the development of the basics of student's general and subject competences. Teachers are encouraged to take bigger responsibility in creating motivating environment that stimulates active learning, the creation of more individualized and integrated contents of education adapted to a greater extent for planning students' achievements and progress, evaluation and selfevaluation have been supported (Sičiūnienè, 2010).

The analysis of the results of scientific researches (Gerulaitis, 2007; Geležinienè, 2009; Makauskienė, 2008; Miltenienè, 2004; Miltenienè, Ruškus, Ališauskas, 2003; Rudyte, 2011) shows that purposeful individualized education, when it is referred to the attitudes of child-focused education and the coordination of the concepts of constructivism and pragmatism developing students' competences and literacy help to achieve better results. From the attitude of social constructivism, social interaction and communication encourage constructing and transforming mathematical knowledge; it is an active process of the construction of meanings when students construct their knowledge and skills communicating with others, referring to learning from the others and their own experience (Berger, Luckman, 1999). However, in the practice of Lithuanian mainstream schools there is still lack of more extensive empirical researches revealing the impact of the construction of enabling educational systems and methods for senior class students of mainstream schools having moderate special educational needs oriented to the development of functional mathematical literacy of these students.

The analysis of scientific literature (Farrel, Dyson, Hutcheson, Gallanaucgh, 2007; Meijer, 2001; Mitchell, 2008; Gillies, 2002, cit. Rodezno, 2008; Nind, Wearmouth, 2006; Poulisse, 2002, cit. from Koopmans-van Noorel, 2009; Lipsky, Gartner, 1997; Warger, Pugach, 1996, Timmons, Breitenbach, 2004, cit. from Lynch, Irvine, 2009; Ališauskas, Ališauskienè, Gerulaitis, Kaffemanienè, Melienè, Miltenienè, 2011 etc.) permits to state that in literature many factors and strategies conditioning the success of integration and inclusion are indicated and they can also be applied in the process of the development of functional mathematical literacy in students with moderate special educational needs. The aforementioned strategies should be flexible in the sense of time, place and form. It requires positive school environment and openness.

In the process of initiating the changes in the system of mathematical education, creating the methodology of the development of functional mathematical literacy in students with moderate special educational needs (foreseeing activities, measures, methods and evaluating their effectiveness) action research using the method of focus group has been applied. In planning the action research, foreseeing the activity in focus groups the factors discovered in earlier stages of the research and related to the concept of functional mathematical 
literacy and the situation of education meeting special educational needs in mainstream schools were taken into consideration. In creating the methodology of functional mathematical literacy for students having moderate special educational needs action research has been organized (Kemmis, McTaggart, 1988, 2005; Charles, 1999; Burns, 2000; McNiff, 2002; Baranauskiene, Ruškus, 2004; McNiff, Whithead, 2009; Reason, Bradbury, 2006; Gelžinienė, 2009 etc.), using the elements of the method of focus group (Belanovskij, 2001; Ehigie, Ehigie, 2005; Rupšienè, 2007, Wilkinson, Birmingham, 2003 etc.). For data processing the methods of content analysis (Merkys, 1995, Burns, 2000, Belanovskij, 2001, Rupšienè, 2007 etc.) and statistical data analysis have been applied.

It has been attempted to ensure the feedback criterion when planning and discussing the research process together with all the participants of the research. Rodezno (2008), Mitchel (2008) present a generalized list of strategies of educating students with special educational needs in mainstream school that was offered to the teachers of mathematics and special pedagogues during the action research to test together with educational methods and measures they use and a prepared exercise book in modelling the methodology of the development of functional mathematical literacy in senior class students of mainstream schools having moderate special educational needs: cooperative learning, authentic learning, peer tutoring, maintaining positive behaviour in school, involving parents, maintaining physical environment and measures, psychological climate of a classroom, development of social skills, teaching cognitive strategies, selfregulating learning, forming assessment and feedback.

During the action research the authors followed the opinion that students with moderate special educational needs should be educated together with peers adapting the content of the programme of mathematics for the $8^{\text {th }}$ form of mainstream school omitting certain topics not understandable for students, applying active methods and paying more attention to practical application of knowledge. Pedagogues during the research were asked to refer to the statement by King-Sears (2008), that children with learning disabilities can learn the same subjects as their peers, but it is very important how it is made (cit. Ališauskas, Ališauskienè, Gerulaitis, Kaffemanienè, Melienè, Miltenienè, 2011).

During the process of the development of mathematical literacy teachers are suggested using Universal Design for Learning that refers to the philosophy that it is necessary to choose appropriate teaching methods and ways of presenting the subject of mathematics to students. The authors follow the attitude that it is not a student who has to adapt himself/herself to pedagogue's teaching style but the contents and methods of the subject should be coordinated in such a way that every student could have equal opportunities to strive for the best individual results (cit. Ališauskas, Ališauskienè, Gerulaitis, Kaffemanienè, Melienė, Milteniene, 2011). The most important principles of the realization of these 
attitudes: learning environment should be supporting; learning process should be organized flexibly with regard to how students accept information, how they perceive it and how they express the knowledge they possess; mistakes are admitted and tolerated; learning should not require physical efforts; the contents of the subject are easily understood, too complicated things are omitted; learning material for students is easily accessed, the environment necessary for learning is foreseen (Burgstahler, 2009; Scott, McGuire, Shaw, 2003, cit. Kumar, 2010). Action research has been chosen in order to initiate changes in the system of mathematical education creating the methodology of the development of mathematical literacy for senior class students of mainstream schools having moderate special educational needs oriented towards the development of functional students' abilities. Action research according to Baranauskiene (2003), Adomaitienè, Zubrickienè, Teresevičienè (2007) is an excellent opportunity to integrate theory and practice and ensure their harmony. Performing the action research pedagogues and researchers can observe how learning environment is changing, reflect on their actions, interactions with students, evaluate the effectiveness of applied methods in developing mathematical literacy in senior class students of mainstream schools having moderate special educational needs. The precondition is made that gained experience can be useful in further analysis and improvement of one's own educational activity because the exceptional advantage of this action research is the improvement of the quality of practice: the better the practitioners perceive their activity the more consistently they try to improve it (Kemmis, McTaggart, 1982; Carr, Kemmis; 1986; Baranauskiene, 2003). The concept of action research (for the first time it was used in 1942 in Lewin's theory) is closely related to the pragmatic theory of cognition by Dewey (2008). According to Jurašaite-Harbinson (2004), action research is an invitation to learn, solve complicated and quotidian professional problems. The result of action research the recommendations on how to create the programmes (in this case - how to model the methodology of the development of functional mathematical literacy in students with moderate special educational needs adapting the general programme of mathematics for the $8^{\text {th }}$ form), and the basis for cognition is the existence of the reality here and now, people's (pedagogues') ability to solve problems, analyzing their own activity in developing the ability of students with special needs to relate mathematical knowledge to real life, to apply in practical activity. Various models of action research are presented in scientific discourse, but the essential feature that unites them - action research as a cyclical, spiral process, during which planning, action, reflection and evaluation take place.

During the research the classical model of action research suggested by $\mathrm{K}$. Lewin was referred to, which is a cyclical process comprising planning, action, observation and reflections, oriented to the analysis of personal interaction with the participants of the process of education and joint activity 
initiating changes in the reality of the process of education. In action research surveys are combined with the participation in it when the researcher can no longer be a passive observer. The method of action research is used searching for the ways of the solution of practical problems during the lessons of mathematics in order to develop mathematical literacy of students with moderate special educational needs.

The stages of the research had been already foreseen before the beginning of the experiment that took place in the all academic year. Referring to a classical model of action research suggested by K. Lewin, theoretical model of the creation of the methodology of the development of universal mathematical literacy and the results of the analysis of the situation of the development of mathematical literacy in students with moderate special educational needs in Lithuania performed in the primary stage the plan of actions and the proceedings of the action research were created. During the process of the research the action plan and the procedure of the action research have been created, during which three meetings of pedagogues (at the beginning of the research, in the middle of the academic year (after semester I) and at the end of the research (after semester II)) have been organized (the method of focus group has been used), semi-structured interviews with teachers and students have been performed, the effectiveness of the application of the created methodology and students' answers to the tasks of a mathematical questionnaire have been discussed.

The methodology of the research should be treated as semi-structured because tasks and the basics of methodology are foreseen in advance (referring to matching the conceptions of pragmatism and constructivism and regarding the peculiarities of the didactic process of mathematics in mainstream school, the requirements of the general programme in mathematics for the $8^{\text {th }}$ form the exercise book for students has been prepared, the basics of the methodology of the development of functional mathematical literacy have been considered), while concrete actions and decisions are dictated by the reality of education and individuality of an educative situation. In the exercise book tasks of practical character are foreseen, that help a student to understand the basics of learning material, to develop general mathematical abilities according to the fields of mathematical activity foreseen in the General Programme, to relate theoretical subjects of the programme of mathematics to practical application of knowledge; learning strategies are presented.

During the first meeting the situation of the development of functional mathematical literacy in $8^{\text {th }}$ form students having moderate special educational needs in mainstream schools of Lithuania has been identified; the decisions were made on what should be changed in the system of mathematical education and how teaching should be organized so that it is more oriented towards practical formation of mathematical knowledge and abilities, the priorities of changes were identified, the research questions were formulated together, the strategies 
of activity were foreseen. The identification of problems and challenges and their solutions took place referring to the experience of group participants, discussing the experiences together, interpreting them and discussing with the other participants of the group. During other discussions of the pedagogues the achievements of performed activity and observations were discussed, reflections were made, the experience how special educational needs are met in foreign countries and Lithuania presented in scientific literature was introduced, the guidelines of further activity were foreseen (re-planning), re-action, reobservation and re-reflection of the whole activity took place. The analysis of the research data took place in two stages, performing content analysis (grouping according to semantic relations, nominating distinguished categories and naming the category) and data interpretation searching interrelations between the categories. Various experience of the participants of the research permitted to reveal structural and depth aspects of their experience in meeting special educational needs during the classes of mathematics and, referring to positive experience, to foresee the directions of positive changes in the development of functional mathematical literacy in $8^{\text {th }}$ form students with moderate special educational needs, to get involved in testing the modelling of suggested methodology in practical activity.

The article presents only some obtained results that show the change in pedagogues' attitude towards the possibilities of the development of mathematical literacy in students having moderate special educational needs applying the methodology of the development of mathematical literacy oriented towards the development of students' functional abilities.

Analyzing the data obtained during the discussions it has been noticed that after the meetings the pedagogues started to look more positively to the possibilities of the development of mathematical abilities in students having moderate special educational needs, the pedagogues accepted the importance of student's participation in the discussion of his/her educational achievements and his/her ability to discuss about it, to get involved in common classroom activity, when appropriate teaching (learning) strategies oriented towards active application of knowledge and abilities, relating to real life experience are applied.

Generalizing the answers to the question that was presented at the beginning of every discussion "Indicate several $(2-3)$ things that are, in your opinion, very important in developing mathematical literacy in students with moderate special educational needs" the priority areas for the teachers of mathematics in educating students with moderate special educational needs were identified, the changes that took place during the research applying the methodology of the development of functional mathematical literacy were noticed (Table 1). 
Table 1

\section{Priority areas in educating students with moderate special educational needs during the classes of mathematics*}

\begin{tabular}{|c|c|c|}
\hline \multicolumn{3}{|c|}{ Categories and subcategories } \\
\hline First evaluation (49) & Second evaluation (50) & Third evaluation (58) \\
\hline $\begin{array}{l}\text { Knowledge, abilities, } \\
\text { results (14) }\end{array}$ & $\begin{array}{l}\text { Acknowledgement of } \\
\text { student's individuality (8) }\end{array}$ & Knowing a student (8) \\
\hline $\begin{array}{l}\text { Orientation towards a } \\
\text { disorder (9) }\end{array}$ & Knowing a student (7) & $\begin{array}{l}\text { Acknowledgement of student's } \\
\text { individuality and individualization of } \\
\text { activity (8) }\end{array}$ \\
\hline $\begin{array}{l}\text { Specialists' assistance to a } \\
\text { pedagogue (6) }\end{array}$ & Positivity (6) & Orientation towards assistance (6) \\
\hline $\begin{array}{l}\text { Good psychosocial } \\
\text { feeling (5) }\end{array}$ & $\begin{array}{l}\text { Good psychosocial feeling, } \\
\text { social adaptation (5) }\end{array}$ & $\begin{array}{l}\text { Application of methodical } \\
\text { instruments (5) }\end{array}$ \\
\hline Knowing a student (5) & $\begin{array}{l}\text { Practical application of } \\
\text { methodical instruments and } \\
\text { educational methods (5) }\end{array}$ & Collaboration with specialists (5) \\
\hline $\begin{array}{l}\text { Communication and } \\
\text { collaboration with a } \\
\text { student (4) }\end{array}$ & $\begin{array}{l}\text { Orientation towards } \\
\text { assistance (4) }\end{array}$ & Positivity (5) \\
\hline Positivity (2) & Learning motivation (4) & Involving parents (4) \\
\hline $\begin{array}{l}\text { Orientation towards } \\
\text { assistance (2) }\end{array}$ & $\begin{array}{l}\text { Orientation towards a } \\
\text { disorder (problem) (3) }\end{array}$ & Learning motivation (3) \\
\hline \multirow[t]{8}{*}{ Peer tutoring $(1)$} & $\begin{array}{l}\text { Involving parents in the } \\
\text { assistance (2) }\end{array}$ & $\begin{array}{l}\text { Orientation towards a disorder } \\
\text { (problem) (3) }\end{array}$ \\
\hline & $\begin{array}{l}\text { Communication with a } \\
\text { student (2) }\end{array}$ & Knowledge, results (3) \\
\hline & $\begin{array}{l}\text { Collaboration, sharing the } \\
\text { results with other } \\
\text { participants (2) }\end{array}$ & Perfection and initiative (2) \\
\hline & Planning (individual) (2) & Student's enablement (2) \\
\hline & & Empathy (1) \\
\hline & & Collaboration (1) \\
\hline & & Social adaptation and integration (1) \\
\hline & & Sharing information with others (1) \\
\hline
\end{tabular}

*Recorded number of lexical-semantic units in one or another category is indicated in brackets next to the statements

The obtained results of the research have shown that during the first evaluation in the category "Priority areas in educating students with moderate special educational needs during the classes of mathematics" the following subcategories have become the most distinct knowledge, abilities, results, orientation towards a disorder, specialists' assistance to a pedagogue. The majority of lexical-semantic units has been recorded in the subcategory of knowledge, to which the statements that accentuate the importance of the results and teaching, programme requirements that, in pedagogues' opinion, will be important in future for students with moderate special educational needs when there are no adapted programmes, have also been attributed to this subcategory. 
Teachers of mathematics often stated that it is important for a student to gain knowledge; it is important to present learning material; it is important that learning results are better; that students learn to adapt to a common classroom pace or do at least a part of the tasks that other students do, when there are no adapted programmes, they will have to test their knowledge, take exams, we do not know that knowledge they will need then. Often the pedagogues accentuated the aspiration to exactly name, identify or diagnose disorders a child has; to find out about student's difficulties, problems. Such statements reflect the pedagogues' orientation towards a disorder and problems. Lexical-semantic units related to student's good psychosocial feeling, the importance of communication and collaboration with a student, positivity have been recorded a little more rarely, and especially rarely - to orientation towards appropriately organized assistance to a student, application of educational strategies and active methods, orientation not towards mastering the knowledge but towards the reorganization of the process of education itself, the development and formation of practical (but not theoretical) mathematical abilities.

The results of the second evaluation that took place after the semester I have shown that the pedagogues' priorities essentially changed. During this stage the subcategories of acknowledgement of student's individuality and knowing a student, positivity, good psychosocial feeling, social adaptation, and teaching (learning) strategies (practical application of methodical instruments and educational methods, etc.) have become distinct. The participants accentuated that it is the most important to accept the student as he/she is and assign tasks according to his/her abilities, to try to understand him/her and be his/her friend. The subcategory of positivity is reflected by the following statements: positive attitude towards such a student and his/her problems is important; not to forget to praise him/her for the progress or the work he/she made; accentuate the progress. Therefore, the importance of knowing a student, good child's feeling were quite often mentioned, more rarely - communication, sharing information, orientation towards a disorder, orientation towards assistance, students' learning motivation, planning. After second evaluation the subcategories such as knowledge, collaboration (abstract concepts), assistance to pedagogues were not recorded at all.

During the discussions about the activity of the first semester the pedagogues mentioned that the pedagogues need less assistance because now students with special educational needs more often (it is a pity that it happens in another way, too) get involved in the classroom activity, they have what to do during a lesson, now it is not necessary to search for tasks completely unrelated to the topic of the lesson for a student that often, because it is possible to give him/her an exercise book, it is only necessary to find a relevant topic. The teachers of mathematics were glad with the collaboration with a special pedagogue, improved communication with students. 
The third evaluation that took place at the end of the academic year showed that knowing a student, acknowledgement of student's individuality and individualization of activity, orientation towards assistance to a student, teaching (learning) strategies (practical application of methodical instruments and educational methods, etc.), collaboration with specialists, orientation towards a disorder (but relating it more to foreseeing assistance), positivity, involving parents, sharing information remained as the priority areas. The teachers of mathematics having indicated the subcategories knowledge, results, orientation towards a disorder, pointed out that these issues are necessary in adapting the general programme of mathematics, foreseeing the directions of assistance). It is enjoyable that during the second and third evaluation the teachers started to think that they should share their positive work experience, information with other teachers, participants of the process of education.

Having generalized the answers to the questions "The difficulties I face in developing functional mathematical literacy in students having moderate special educational needs" the category of difficulties the pedagogues face has been identified. In this category during the first evaluation the majority of lexicalsemantic units have been recorded in the subcategories of management of time and lesson, lack of assistance, student's disorder. In the proceedings of the research the pedagogues more and more rarely related occurring difficulties to the factors that cannot be changed or almost cannot be changed (student's disorder, abundance of documentation, etc.), but started to analyze them on the individual level when personal responsibility is important.

\section{Conclusions}

- The analysis of scientific researches and sources of methodical literature shows that purposeful individualized education, when it is referred to the attitudes of child-focused education and the coordination of the concepts of constructivism and pragmatism developing students' competences and literacy help to achieve better results.

- The action research using the method of focus group permitted the pedagogues to reflect and regroup the priorities of the methodology of mathematical education and the activity in developing functional mathematical literacy in $8^{\text {th }}$ form students having moderate special educational needs: orientation towards knowledge and results, accentuation of a disorder were changed and complemented by the aspiration to acknowledgement of child's individuality, orientation towards assistance regarding student's strengths, purposeful use of teaching (learning) strategies oriented towards practical application of mathematical knowledge in the process of education and life. 
- It has been noticed that participation in the research had influence on pedagogues' general competences related to personal perfection and personal general abilities, as well as the abilities in the field of special education (orientation of the system of mathematical education for students with special educational needs towards the development of functional mathematical literacy). The changes in value attitudes towards a child with moderate special educational needs (acknowledgement of individuality of a child with SEN, knowing a student, positivity, etc.) have been observed. Assistance in learning how to plan time and organize work in a classroom where students with moderate special educational needs study together with students of different abilities is relevant to pedagogues. Difficulties arise because of lack of specific knowledge and methodological literature and methodical instruments, which the authors tried to compensate by suggesting that the pedagogues test the prepared methodology of developing functional mathematical literacy.

\section{Bibliography}

1. Adomaitienè, J., Zubrickienè, I., Teresevičienè, M. (2008). Profesijos mokytoju ir dèstytojų tobulejimas, atliekant veiklos tyrimus. Profesinis rengimas. Tyrimai ir realijos. Nr. 15. Kaunas: VDU. P. 10-21.

2. Ališauskas, A., Ališauskienè, S., Gerulaitis, D., Kaffemanienė, I., Melienė, R., Milteniené, L. (2011). Specialiujų ugdymo(si) poreikių tenkinimas: Lietuvos patirtis užsienio šalių kontekste. Šiauliai.

3. Baranauskienè I., Ruškus J. (2004). Neigaliuju dalyvavimas darbo rinkoje: profesinio rengimo ir profesinés adaptacijos squeika. Šiauliai: VŠ Šiaulių universiteto leidykla.

4. Baranauskienè, R. (2003). Emancipaciniu kokybiniu tyrimu realizavimas edukacinès paradigmos virsmo kontekste. Šiauliai.

5. Berger, P., Luckman Th. (1999). Socialinis tikrovès konstravimas. Vilnius.

6. Bitinas, B. (2000). Ugdymo filosofija. Vilnius.

7. Burns, R. B. (2000). Introduction to Research methods. London, Thousand Oaks, New Delhi:SAGE Publication.

8. Charles, C. M. (1999). Pedagoginio tyrimo ìvadas. Vilnius: alma littera.

9. Dewey.J.(2008). Democracy and and Education. http://en.Wikisource.org/wiki/Democracy_and_Education.

10. Ehigie, B., Ehigie, R. (2005). Applying gualitative methods in organizations: a note for industrial/ organizational psychologists. The Qualitative Report 10(3). P. 621-638.

11. Geležinienè, R. (2009). Irodymais gristos mokytoju veiklos konstravimas ugdant emociju ir elgesio sutrikimu turinčius mokinius. Daktaro disertacija. Šiauliai: Lucilijus.

12. Gerulaitis, D. (2007). Tévu isitraukimo i vaiko ugdymo(-si) procesa plètoté specialiojoje mokykloje. Daktaro disertacija. Šiauliai: Šiaulių universiteto leidykla.

13. Jurašaitė-Harbison, E. (2006). Veiksmo tyrimo vaidmuo siekiant profesionalumo. Gimtasis žodis. [žiūrèta 2012-01-24]. Prieiga internete: $<\mathrm{http}: / /$ www.gimtasiszodis.w3.1t/jurasaite_04_6.htm.

14. Kemmis, S., McTaggart, R. (1988). The Action Reseach Planner. Geelong: Deakin University. 
15. Press.Kemmis, S., McTaggart, R. (2005). Participatory Action Research. Communicative Action and the Public Sphere. (p. 559 - 603). Denzin, N.K., Lincoln, Y.S. (Ed.). (2005). The Sage Handbook of Qualitative Research. London: Sage Publications.

16. Koopmans-van Noorel, A. (2009). The design of the curriculum for pupils with mental disabilities in mainstream primary education in the Netherlands: The complex practice and the bottlenecks from a teacher's perspective. Paper for the ECER $\mathrm{n}$ Vienna, September 28-30. SLO National Institute for Curriculum Development, The Netherlands.

17. Kumar, K. (2010). A journej towards creating an inclusive classroom: How Universal Design for Learning has transformed my teaching. Transformative Dialogues: Teaching \& Learning Journal, Vol. 4, Iss.2 November, 1-5.

18. Lynch, Sh. L., Irvine, A., N. (2009). Inclusive education and best practice for children with autism spectrum disorder: an integrated approach. International Journal of Inclusive Education, Vol. 13, No. 8, 845-859.

19. Makauskienè, V. (2008). Logopedinès pagalbos mikčiojantiems moksleiviams modeliavimas i vaika orientuoto ugdymo paradigmoje Daktaro disertacija. Šiauliai: Šiaulių universiteto leidykla.

20. McNiff, J. (2002). Action Research for professional development: Concise advice for new action researchers. [žiūrèta 2012-01-24]. Prieiga internete: http://www.jeanmeniff.com/ar-booklet.asp.

21. McNiff, J., Whithead, J. (2009). Your and Your's Action Research Project. 3thrd Edition. NY: Routledge.

22. Meijer, C. J. W. (Ed) (2001). Inclusive Education and Effective Classroom Practice. European Agency for Development in Special Needs Education.

23. Merkys, G. (1995). Pedagoginio tyrimo metodologijos pradmenys. Šiauliai: ŠPI.

24. Mitchell, D. (2008). What Really Works in Special and Inclusive Education. Using evidence-based teaching strategies. Rouledge.

25. Miltenienè, L. (2005). Bendradarbiavimo modelio konstravimas tenkinant specialiuosius ugdymosi poreikius. Daktaro disertacija. Šiauliai: Šiaulių universitetas.

26. Miltenienè, L., Ruškus, J., Ališauskas, A. (2003). Tẻvų, auginančių specialiujų ugdymosi poreikių turinti vaiką, nuostatos i dalyvavimą ugdymo procese, struktūra ir raiška. Specialusis ugdymas: mokslo darbai, 2003, Nr. 2 (9), p. 24-37.

27. Ozmon, H. A., Craver, S. M. (1996). Filosofiniai ugdymo pagrindai. Vilnius: Leidybos centras.

28. Pradinio ir pagrindinio ugdymo bendrosios programos. (2008). Vilnius: Švietimo aprūpinimo centras.

29. Reason, P., Bradbury, H. (Sud.). (2006). Handbook of action research. London: Sage.

30. Rodezno, N. (2008). Practising inclusion within regular school setting: students with special needs and their Apener experience. A thesis submitted as a partial fulfilment of the degree of doctor of education. Australian Catholic University research Services, Australia.

31. Rupšienė, L. (2007). Kokybinio tyrimo duomenų rinkimo metodologija. Klaipėda: Klaipėdos universiteto leidykla.

32. Rūdytè, K. (2011). Vaiku savaiminio mokymo(si) kultūros socialinis-edukacinis diskursas i vaika orientuotoje paradigmoje. Daktaro disertacija. Šiauliai: Šiaulių universitetas.

33. Sičiūnienè, V. (2010). Matematikos didaktika : metodiné priemoné. Vilnius: Vilniaus pedagoginio universiteto leidykla.

34. Wilkinson, D., Birmingham, P. (2003). Using Research Instruments: A guide for Researcher. London and New York: Rouledge Falmer, Taylor \& Francis Group.

35. Белановский, С. А. (2001). Метод фокус-групn. Москва: Никколо-Медиа. 


\begin{tabular}{|r|l|}
\hline Ingrida & Šiauliai University, Faculty of Social \\
Baranauskienè & Welfare and Disability Studies \\
& P. Višinskio str. 25, LT-76351 Šiauliai, \\
& Lithuania \\
& E-mail: i.baranauskiene@cr.su.lt \\
& Phone:+370 41 595730 \\
\hline Laima Tomėnienè & Šiauliai University, Faculty of Social \\
& Welfare and Disability Studies \\
& P. Višinskio str. 25, LT-76351 Šiauliai, \\
& Lithuania \\
& E-mail: laimatom@gmail.com \\
\hline
\end{tabular}

